\title{
QUESTIONE MERIDIONALE AND GLOBAL SOUTH: IF THE ITALIAN SOUTH MEETS ITS GLOBAL BROTHER
}

\section{LUIGI CAZZATO}

\begin{abstract}
Sommario
Il saggio prova ad affrontare la vexata questio meridionale alla luce di quello che è stato il dibattito italiano negli ultimi anni a partire dai benevoli influssi degli studi postcoloniali e del cosiddetto "pensiero meridiano". Partendo dall'imagery africana dominante (orientalista e non) con cui spesso il sud d'Italia è stato descritto (immagini legate allidea di natura selvaggia e cultura arretrata), si cerca di leggere lo scontro avvenuto fra modernità e tradizione attraverso le categorie gramsciane egemonia/subalternità e l'ermeneutica del ri-morso di E. De Martino. Questo approccio sembra di interrogare e valutare meglio la storia del famigerato "ritardo" del Mezzogiorno, storicamente misurato attraverso $i$ parametri "settentrionali" dell'ideologia modernista del progresso, e, soprattutto, di rimuovere quel velo culturale che impedisce di vedere la storia di questa regione del Mediterraneo come storia postcoloniale. Infine, si cerca di raccontare che cosa avviene quando il sud italiano (che è però nord del pianeta) e quello globale si incontrano, e che cosa questa esperienza potrebbe insegnare al pianeta, inteso demartinianamente, come terra globale del rimorso.
\end{abstract}

The Mezzogiorno as the Italian Africa

Let's start with a scenario: the South-eastern point of Italy's heel, further south-east than Naples, Paestum, Herculanæum and Pompeii, where most 
English travellers used to end their Grand Tour and most gothic novel writers began their fictional one (Walpole's The Castle of Otranto, 1764; Radcliffe's A Sicilian Romance, 1790). Exactly, we are in the Salento . The year is 1959. In this remote corner of Italy, a scientific team led by the great Italian ethnologist Ernesto De Martino is conducting fieldwork for a study about 'tarantism', a form of possession believed to result from the bite of a mythical tarantula ('spider') and its ritual cure with the tarantella dance:

Scorgemmo un capannello di gente davanti un basso, localizzammo subito la casata da cui giungevano i suoni: affrettammo il passo, fummo davanti la porta, ci facemmo largo tra la gente ricambiando con un ovvio sorriso i molti occhi in atto di chiedersi: "Chi sono questi forestieri?" e finalmente di punto in bianco, dal giorno alla notte, ci trovammo brutalmente sbalzati in un altro pianeta... Qui [a miserabile one-room dark dwelling], nei limiti segnati dalla bianca tela, si produceva la tarantata, anch'essa in bianco come la tela su cui danzava, la vita stretta da una fascia, la nera capigliatura tempestosamente sciolta e ricadente sul volto olivastro, di cui si intravedevano ostentatamente immobili e duri e gli occhi ora chiusi e ora socchiusi, come di sonnambola, mentre il chitarrista, il fisarmonicista, la tamburellista e il nostro barbiere-violinista si producevano a loro volta nella vibrante vicenda della terapia sonora. (De Martino 2002:66)

\footnotetext{
The Salento, a subregion of Apulia, is a South-Eastern region of Italy, separated from the Balkan Eastern coast by a narrow strech of sea, which cannot prevent you from seeing the opposite mountainous coast on clear days when the north wind blows. It is quite far from the NorthAfrican coast, but Africa nonetheless makes itself felt through the sandy winds that often push clouds full of Sahara sand up north, sometimes as far as Rome.
} 
The world in which they were brutally cast was more or less the same as the one an $18^{\text {th }}$ century eyewitness had once described in The Gentleman's Magazine $^{2}$. He was a musician who, strangely, was asked to play the violin to a man who had been found collapsed in the street. Not being familiar with the tarantella, he played a jig which failed to have any successful result. Then an elderly woman started to sing and the musician began to follow the tune, provoking a reaction: "the man began to move to the rhythm of the music, lifting himself to his feet like a thunderbolt, giving the appearance of a man who had awoken from a terrible vision, his gaze fixed and wild, with every joint of his body in motion"3. When the violin player stopped, the man dropped back to the floor in a convulsive fit. As soon as the player restarted playing, the man was back on his feet, dancing again like a spirited performer.

The Neapolitan scholar, founding figure of Italian cultural anthropology, similarly witnessed the last remnants of 'the strange malady', an archaic pagan cultural phenomenon in the midst of a modernising Italy, shortly before the economic boom of the Sixties would explode. He called this land Terra del Rimorso. The translation of such an expression is a difficult one. We could simply say 'land of remorse' but this unfortunately would not maintain its twofold meaning: 'rimorso' can be both 'regret' and 're-bite' (a 'morso' is a 'bite'). Only if we interpret 'rimorso' as rebiting regret can we understand why De Martino considered this land as the land of the "cattivo passato che torna [and rebites] e che si ripropone alla scelta mondana riparatrice" (De Martino

2 Speaking of this continuity and immobility of Italian socio-cultural environment, it is interesting to report what W.H. Auden said about post-Second World War and pre-French-Revolution Italy, in his introduction to Goethe's Italian Journey: "I am amazed at their similarity. Is there any other country in Europe where the character of the people seems to have been so little affected by political and technological change?" (Auden 1970:8).

3 The Gentleman's Magazine, August 1743, 13:422. 
2002:272). In other words, the ethnologist maintained that tarantism had provided a liminal zone into which class and gender oppression - that is to say, erotic covert desires, frustrated hopes and unresolved grief - could be conveyed and settled through catharsis. The suspected spider's bite, its summer re-surgence (re-bite), and the following dancing-beyondexhaustion cure were just symbols of a 'minor religion', which had emerged in the medieval period (thanks to the widespread cultural connection with Arabs) and flourished until the $18^{\text {th }}$ century. Such beliefs and practices have antecedents in ancient Greece (Dionysian cults) and parallels with many contemporary 'ecstatic' religions similar to some African cults conveyed by Islamic culture since the seventh century.

This is one of the images of the 'Italian Africa' that so many Italian and foreign commentators have seen and spoken of for centuries ${ }^{4}$. The majority of foreigner travellers to Italy assumed for many centuries, as did the French poet Creuze de Lesser as late as the beginning of $19^{\text {th }}$ century, that: "L'Europe finit à Naples et même elle y finit assez mal. La Calabre, la Sicile, tout le reste est de l'Afrique" (Mozzillo 1982:15). Madame de Staël in her novel Corinne ou l'Italie (1807) portrayed Naples and its "immense population, at once so animated and so indolent" as "something extremely original in this state of savage existence, mingled with civilization". For some peculiar reason, their bad manners are somehow uncommon, "they are not boorish in the manner of other peoples. Their very coarseness strikes the imagination. The African shore which is on the other side of the sea can almost be felt already [...]" (Madame de Staël 1998:187). A similar kind of exotic, African, uncouthness was seen in

When I speak of 'Africa' here, I am referring to the stereotypical image of the Mezzogiorno prevailing in Italy, which is largely associated with the northern and central part of the multifaceted African continent. It is an image connected with natural and creative beauty, wilderness, unconscious primitiveness, and from the $19^{\text {th }}$ century onwards with backwardness (that is to say with the delayed progress as opposed to the hectic pace of the modernising process that swept the North-West of the peninsula and of the planet). 
Apulia, where the Salento is located. Janet Ross was an English writer and businesswoman who settled in Tuscany in the second half of the $19^{\text {th }}$ century, who hosted foreign travelers such as Mark Twain and Henry James, and occasionally travelled southwards. She found Apulia a wild and melancholic region. She praised its people for their wonderful Oriental look and behaviour. Its landscape reminded her of the African coast: "Qua e là una palma torreggia alta verso il cielo, piegando le sue foglie leggere come se si struggesse per il suo fratello lontano in Africa" (Cecere 1993:443). Not surprisingly, in such a landscape, magic appears, like in pagan Africa: "nessuna meraviglia che qui la gente creda nelle streghe e nella magia: le desolate distese della campagna, le forme fantastiche del carrubo [...] le innumerevoli tombe, cripte e resti di antichi edifici sparsi un po' dovunque, contribuiscono tutti ad impressionare una popolazione ignorante" (Cecere 1993:443). Putting aside her positivistic explanation of Apulian people's temperament (they believe in magic because of the natural and architectural context), and her paternal, though not too indulgent, attitude towards the Apulian ignorant peasants, her northern Orientalist gaze joins Apulia and Africa together as sister regions, personifying their palm trees looking for each other, trying to restore their fraternal tie broken by the separating sea.

If the roots of this Orientalist, Africanist gaze were foreign, native Italians followed the lead. In George Gissing's account of his southwards ramblings as early as 1897 we can found another analogy between Africa and the Italian South, but this time it is a Neapolitan middle-class family that helps the foreign traveller to sketch it. When he reveals to his host his plan to get to Calabria, he provokes an astonished reaction:

Both are astonished at my eccentricity and hardiness in undertaking a solitary journey through the wild South. Their geographical notions are vague; they have barely heard of 
Cosenza or of Cotrone, and of Paola not at all; it would as soon occur to them to set out for Morocco as for Calabria. How shall I get along with people whose language is a barbarous dialect? Am I aware that the country is in great part pestilential? - la febbre! (Gissing 1996:59)

If, towards the end of the $19^{\text {th }}$ century, Neapolitan middle-class people can perceive their south in this way, it means that both northern Italians (expatriates included) and foreign travellers had already done a good job in joining the stereotyped images of Africa and the Mezzogiorno. As early as 1861 in La Gazzetta di Torino one could read the following: "Per la gran parte di noi l'Italia è un po' come l'Africa per i geografi: ne conosciamo i confini ma poi se vogliamo spingere un po' più in là l'occhio e il pensiero, ci troviamo innanzi - come i geografi nell'Africa le terre ignote".

Later on, during the Fascist Ventennio, Carlo Levi lived his political confinement in the terra incognitae of Lucania. In Cristo si è fermato a Eboli (1945) he famously wrote:

Noi non siamo cristiani, - essi dicono, - Cristo si è fermato a Eboli -. Cristiano vuol dire, nel loro linguaggio, uomo: e la frase proverbiale che ho sentito tante volte ripetere, nelle loro bocche non è forse nulla più che l'espressione di uno sconsolato complesso di inferiorità. Noi non siamo cristiani, non siamo uomini, non siamo considerati come uomini, ma bestie, bestie da soma, e ancora meno che le bestie, i fruschi, i frusculicchi, che vivono la loro libera vita diabolica o angelica, perché noi dobbiamo invece subire il mondo dei cristiani, che sono di là dall'orizzonte, e sopportarne il peso e il confronto. Ma la frase ha un senso molto più profondo, che, come sempre, nei modi simbolici, è quello letterale. Cristo si è davvero fermato a Eboli, dove la strada e il treno 
abbandonano la costa di Salerno e il mare, e si addentrano nelle desolate terre di Lucania. Cristo non è mai arrivato qui, né vi è arrivato il tempo, né l'anima individuale, né la speranza, né il legame tra le cause e gli effetti, la ragione e la Storia. Cristo non è arrivato, come non erano arrivati i romani, che presidiavano le grandi strade e non entravano fra i monti e nelle foreste, né i greci, che fiorivano sul mare di Metaponto e di Sibari: nessuno degli arditi uomini di occidente ha portato quaggiù il suo senso del tempo che si muove, né la sua teocrazia statale, né la sua perenne attività che cresce su se stessa. (Levi 1990:3-4)

In this passage, the pre-Christian (or non-Christian) pagan nature of the South is emphasised once again, but in the non-orientalist way De Martino approached it when observing Apulia people bitten by the tarantula. Not only has Christ not come, but neither History ("il tempo che si muove") nor Progress ("perenne attività che cresce su se stessa") have arrived. Magic is part of the picture even in Cristo si è fermato a Eboli:

Nel mondo dei contadini non c'è posto per la ragione, per la religione e per la storia. Non c'è posto per la religione, appunto perché tutto partecipa della divinità, perché tutto è, realmente e non simbolicamente, divino, il cielo come gli animali, Cristo come la capra. Tutto è magìa naturale. Anche le cerimonie della chiesa diventano dei riti pagani, celebratori della indifferenziata esistenza delle cose, degli infiniti terrestri dèi del villaggio. (Levi 1990:102)

Thus, immediately before the fascist government ferociously occupied Africa, an African context is foregrounded: a pagan place not yet civilised by Christianity (the main 'Western' religion), a place where everything is naturally divine, therefore magic (that is to say opposed to 'Western' 
Reason), where poverty and starvation dwell, and there is no place for History ('Western' Progress). To have a different point of view we have to wait for the second half of the twentieth century. This will be discussed in the next paragraph.

\section{The Archaic within the Modern}

Vittorio Bodini, Salentine poet and translator of Don Quixote into Italian, sang of his distressed, hopeless people before De Martino's survey. In Foglie di tabacco 1945-1947 he writes: "Cade a pezzi a quest'ora sulle terre del Sud / un tramonto da bestia macellata" (Bodini 1997:95). His south is a place where sunset has the non-picturesque colour of blood, because a poor carter driving home "rientra decapitato". Here darkness is neverending, because "tu luna, le incognite finestre / illumini del Nord, / mentre noi qui parliamo, / nel fondo di quest'esule provincia / ove di te solo la nuca appare" (Bodini 1997:98). Although Bodini's Salento is transfigured by his surrealist language, it is still a recognisable homologue of Levi's realistic portrait of Lucania: "Sulle pianure del Sud non passa un sogno. / Sostantivi e le capre senza musica, / con un segno di croce sulla schiena / o un cerchio, / quivi accampati aspettano un'altra vita" (Bodini 1997:93-98). An archaic and static dimension, soundless and flat, emerges (full of magic speechless signs), where people have no hope ("non passa un sogno"); they are just motionless, waiting for another chance ("un'altra vita"). Life is deferred. Or it can be lived only obliquely, once more through the 'strange malady': "uno l'ho visto io / camminare col capo in giù / sul soffitto, / altri bevevano a un pozzo / di scorpioni e di serpi, / non senza gridi, / nel viola acido e sporco / di una cappella" (Bodini 1997:120). Here, the poet is referring to the well-known St. Paul's chapel in Galatina, where the tarantate/i used to go and ask for the cure. 
Therefore, history is absent once again. But if there is no place for history, there is room to question and incriminate it:
Al tempo dell'altra guerra contadini e contrabbandieri si mettevano foglie di Xanti-Yaca [tobacco]sotto le ascelle per cadere ammalati.Le febbri artificiali, la malaria presunta di cui tremavano e battevano i denti, erano il loro giudizio sui governi e la storia. (Bodini 1997:120)

The supposed fever, the 'strange malady', was but the peasants' natural response to culture, to history, or to the oppression of whomever ruled and was in control of culture and history. Their ritual fever was a way of trying to crack or at least of facing their subaltern condition ${ }^{5}$. Bodini although he says that "quando tornai al mio paese nel Sud, / io mi sentivo morire" - nevertheless did not consider his paese's archaic way of living something to be despised from the northern modern perspective he might have embraced (he also lived in Rome, Tuscany, and Madrid). Rather, he found his paese "così sgradito da doverti amare".

Similarly Carlo Levi did not deride the peasants' world ruled by magic, though he say it from his Piedmontese modern point of view. He tried to be respectful and to understand it:

Visitando i malati, mi accadeva molto spesso di vedere, in generale appeso al collo con una cordicella, un fogliolino di

5 This view of the subaltern South is quite clear in his prose writings too. In Squinzano, vino a Milano, an article about the production of wine in the Salento and its invisible northern exploitation, he writes: "Il segreto di questi uomini di Milano [...] è molto semplice. È dovuto a due cause, una terrena, che è la pigrizia dei produttori locali, che fatta l'uva hanno sempre aspettato che gliela venissero a comprare dal Nord, e l'altra soprannaturale. I settentrionali godono di favori di divinità invisibili le quali, dalle nubi in cui sono avviluppate, li assistono e proteggono. Queste divinità sono le Banche, che pesano crediti e prestiti con disuguali bilance" (Bodini 2007:15-16) 
carta, o una piccola piastrina di metallo, con su scritta, o incisa, la formula triangolare:

\section{A}

A B

A B R

A B R A

A B R A C

A B R A C A

A B R A C A D

A B R A C A D A

A B R A C A D A B

A B R A C A D A B R

A B R A C A D A B R A

I contadini, dapprincipio, cercavano di nascondere questo amuleto, e quasi si scusavano con me di portarlo: perché sapevano che i medici hanno l'abitudine di disprezzare queste superstizioni, e di tuonare contro di esse, in nome della ragione e della scienza. E fanno benissimo, là dove la ragione e la scienza possono assumere lo stesso carattere magico della volgare magìa: ma qui, esse non sono ancora, e forse non saranno mai, divinità ascoltate e adorate.

Perciò io rispettavo gli abracadabra, ne onoravo l'antichità e l'oscura, misteriosa semplicità, preferivo essere loro alleato che loro nemico, e i contadini me ne erano grati, e forse ne traevano davvero vantaggio. (Levi 1990:XI)

If for De Martino, from his non-ethnocentric perspective, "il tarantismo non ci è indifferente, e quasi ci costringe a misurare con lui le insidiate 
potenze della nostra modernità" (De Martino 2002:6) ${ }^{6}$, for Levi the peasants' ancient and mysterious practice compels us to assess modern science and confront it. According to Calvino, Levi was "l'ambasciatore di un altro mondo all'interno del nostro mondo", as a consequence, he conveyed the sense of the "compresenza dei tempi" (Calvino 1967:239). In this light, Levi's South was similar to a foray of the archaic within northern modernity. Probably, this is what the Neapolitan anthropologist meant when he finally stated:

[... ] se la Terra del Rimorso è la Puglia in quanto patria elettiva del tarantismo, i pellegrini che la visitarono nell'estate del '59 provenivano da una più vasta terra cui in fondo spetta lo stesso nome, una terra estesa fino ai confini del mondo abitato dagli uomini, e forse oltre, verso gli spazi che gli uomini si apprestano a conquistare: una terra tuttavia che è bella, perché la vita è bella, almeno nella misura in cui, secondo il destino umano, è soccorsa dalla vigile memoria del passato e dalla prospettiva dell'avvenire. (De Martino 2002:273, emphasis added)

Seen in this light, the meaning of the term rimorso is perhaps more conspicuous. The 'powers of our modernity', to say it as De Martino puts it, have to come to terms with what is not modern, with what resists

6 See De Martino: "Il significato-culturale del tarantismo risulta non tanto dal suo rapporto con in paralleli etnografici e con gli antecedenti classici, quanto dal fatto che la sua origine, le sue modalità e il suo declino [...] appaiono legati a momenti decisivi o importanti della stessa storia interna della civiltà occidentale" (De Martino 2002:272). These moments are connected with Christianity and the New Science. Two repressive moments, whose Occidentalist attitude, have chased away the sapient tarantula: the first, under St. Paul's influence, has distorted its institution, transforming its bite into crisis with no cure (only the saint could decide whether or not to grant the cure), the second relegated it to the historical dustbin of irrational archaisms. 
modernity and its Faustian obsessional dream of ceaseless advancement ${ }^{7}$. On the one hand, what appears to be a remnant of ancient irrationality has to be seen as a product of a cultural history endowed with its own forms of rationality: De Martino, of course, did not consider tarantism as natural magic the way the Renaissance did, nor simply as an illness the way modernity does. Instead he saw it as a social institution provided with its autonomous cultural symbols and a rationality of its own. On the other hand, our sense of reason and modernity has to be a precarious one and our historicist or modernist faith is to be balanced with what interrogates this faith. Unfortunately, within the modernist Weltanschauung, everything that does not conform to it is accordingly considered 'residual', doomed to be straightforwardly and unfavourably thrown into the rubbish bin of history. In the Italian case, the rubbish bin of history would be the absence of a history of the south.

Let's move back a little. Benedetto Croce called this southern condition 'non-history': "una storia che non è storia, di un processo che non è un processo perché ad ogni passo interrotto e sconvolto" (De Martino 2007:173). But if it is a disrupted process by what or whom was it interrupted and upset? On could argue by the nations that occupied the Italian peninsula for more than a millennium. Since the fall of the Roman Empire, the Mezzogiorno has been conquered through time by the Visigoths, the Arabs, the Normans, the Swabians, the Angevins, the Aragonese and by the Bourbons.

7 As early as the beginning of the $18^{\text {th }}$ century, another Neapolitan thinker, Gian Battista Vico, in his anti-Cartesian La Scienza Nuova (1725), tried to claim that historical progress is not irreversible and archaisms are not alien to modernity, in the same way as irrationality is not alien to our rational world. As late as the Nineteen -sixties, Italo Calvino seems to warn us in a similar fashion: "Più le nostre case sono illuminate e prospere più le loro mura grondano fantasmi; $i$ sogni del progresso e della razionalità sono visitati da incubi" (Calvino 1995:212). In the same period Bodini wrote in the poem Civiltà industriale: "Ė l'anno dell'avvento della Ragione / il cui trionfo ci costò tante sconfitte" (Bodini 1997:183). 
Only to this extent that is the history written by others, can the concept of southern non-history be accepted: . Or, as the $19^{\text {th }}$ century romantic historian Simone de Sismondi put it, Italy's "sventure non sono altro che episodi nella storia delle altre nazioni" (Gnisci 2007:76). The striking thing here is, once more, the analogy between Mezzogiorno's history and African history: both of them have had their historical process 'interrupted' and 'upset' by external powers. The Burkinabé historian Joseph Ki-Zerbo said something similar when, referring to the Latin motto "vita in motu ab intrinseco", he wrote that "la vita è movimento a partire da se stessa; se un movimento è indotto e imposto dall'esterno non è vita. Applicando questo ragionamento al continente africano possiamo dire che l'Africa è stata privata del suo movimento ab intrinseco, della sua forza di auto-propulsione" (Gnisci 2007:77). That is the source from which the "straordinaria potenza del negativo nella storia del sud" (De Martino 2007:174) springs forth. It comes from the condition of Italy as Colonia Europae, as Gnisci trenchantly puts it (according to him we could even trace this colonising process back to Magna Grecia), and the Mezzogiorno as, I add, Colonia Italiae Boreae. That is to say, it is the condition in which a community has been deprived of autonomous movement, of selfpropulsion. The 'land of remorse' is, therefore, every land where the evil past comes back to haunt its subaltern dwellers because it has a "passato che non fu scelto" (De Martino 2002:13) but imposed by the history of others. As Chambers convincingly claims, the grammar of hegemonic historiography

può essere dissipata, l'idea di "progresso" accantonata, e la "logica" della "storia" può aprirsi alle interrogazioni poste da coloro che sono stati espulsi dal racconto, ovvero da quelli "senza storia" che sono stati brutalmente esclusi, o semplicemente obliterati, dal progresso. Qui, come Dipesh 
Chakrabarty ci rammenta, viene a galla ciò che resta profondamente "sottosviluppato" nella coscienza occidentale e nell'elaborazione della storia e della sua "modernità". (Chambers 2007:115)

However, the redistribution of the power of language and the opening of a counter-narrative space is not all. What is undeveloped in our western conscience is the idea of plural history, the idea of a non-homogenous modernity, irregular, non-linear. In short, history is much more complicated than we would like it to be, and modernity much more heterogeneous. The questione meridionale is a typical example of the complex nature of history.

\section{The Mezzogiorno as Colonia Italiae Boreae}

Italian colonialism did not begin towards the end of the $19^{\text {th }}$ century with the invasion of portions of Africa that were still free from colonization (Eritrea, Somalia, Abyssinia) - but earlier on with the unification of Italy or, more correctly, with the military annexation of the Bourbons' Kingdom (as a result, the Bourbons were just the second-last colonisers). The start of this 'inner colonialism' is beautifully rendered in Tomasi di Lampedusa's Il Gattopardo (1958), when the Piedmontese Chevalley makes a slip of the tongue while exposing his southern political mission to the Principe di Salina: "Dopo la felice annessione, volevo dire dopo la fausta unione della Sicilia al Regno di Sardegna, è intenzione del governo di Torino di procedere alla nomina a Senatori del Regno alcuni illustri siciliani [...]" (Tomasi di Lampedusa 2002:140). And the dramatic irony continues when, after Don Fabrizio's speech about Sicily's historical subalternity, Chevalley keeps on stating: "Ma ad ogni modo questo adesso è finito; adesso la Sicilia non è più terra di conquista ma 
libera parte di un libero stato" (Tomasi di Lampedusa 2002:143). But it was not. Earlier il Principe di Salina slyly and accurately tried to explain to the Savoyard the reasons why he might accept the new government's proposal only if it were some kind of ritualistic sinecure:

Abbia pazienza, Chevalley, adesso mi spiegherò; noi Siciliani siamo stati avvezzi da una lunghissima egemonia di governanti che non erano della nostra religione, che non parlavano la nostra lingua, a spaccare i capelli in quattro. Se non si faceva così non si sfuggiva agli esattori bizantini, agli emiri berberi, ai vicerè spagnoli. Adesso la piega è presa, siamo fatti così. Avevo detto "adesione" non "partecipazione". In questi sei ultimi mesi, da quando il vostro Garibaldi ha posto piede a Marsala, troppe cose sono state fatte senza consultarci perché adesso si possa chiedere a un membro della vecchia classe dirigente di svilupparle e portarle a compimento; adesso non voglio discutere se ciò che si è fatto è stato male o bene; per conto mio credo che parecchio sia stato male; ma voglio dirle subito ciò che Lei capirà da solo quando sarà stato un anno fra noi. In Sicilia non importa far male o far bene; il peccato che noi Siciliani non perdoniamo mai è semplicemente quello di "fare". Siamo vecchi, Chevalley, vecchissimi. Sono venticinque secoli almeno che portiamo sulle spalle il peso di magnifiche civiltà eterogenee, tutte venute da fuori già complete $\mathrm{e}$ perfezionate, nessuna germogliata da noi stessi, nessuna a cui abbiamo dato il "là"; noi siamo dei bianchi quanto lo è lei, Chevalley, e quanto la regina d'Inghilterra; eppure da duemila cinquecento anni siamo colonia. Non lo dico per lagnarmi: è in gran parte colpa nostra; ma siamo stanchi e svuotati lo stesso. (Tomasi di Lampedusa 2002:143, emphasis added) 
Don Fabrizio's predicament does not leave anyone untouched, neither the invader nor the invaded. One thing is sure though: the making of Italy has not been performed at all in the right way, and Sicily has always been a 'white colony'. Is it only the viewpoint of a southern writer? Let us see then what some non-southerners thought and said.

Before speaking of Italian Africa, the colonialist talk was about 'India Italiana'. The idiom took root as early as the mid- $16^{\text {th }}$ century, when counter-reformist Jesuits tried to spread their missionary activities in the Italian South. In a 1561 letter from Calabria, Cristoforo Madrid stated: "È la gente tanto assuefatta al male, sono tanto licenziosi, superbi, senza giustizia et governo come se fussero tutti del bosco. Delli preti non voglio cominciare: basterà che a bocca potremo dare occasione alli nostri fratelli di venire in questa India" (De Martino 2002:22-23). This local India is so 'Indian' that it might be suitable for missionary novices, as Michele Navarro, who lived in Calabria and Sicily for some months, pointed out in 1575: "Ho infatti per certo che chiunque darà buona prova di sè in queste nostre Indie di qui, sarà adatto anche a quelle di là dell'Oceano: così come chi troverà difficoltà nel viaggiare e nel patire in queste, non sperimenterà certo nelle altre molta facilità" (De Martino 2002:23). But the assimilation of the old Italian South to the New World as a land to be civilised is still at issue soon after unification, if the new senators could compare the southern peasants to the savages of America. It was Nino Bixio, exgaribaldino and high-ranking officer of the new 'unified' state, who expressed very clearly his orientalist and racist view. He considered Neapolitans 'Orientals' because they could understand only brute force:

Abbiamo visitato alcuni paesi del Molise. Che paesi! Si potrebbero chiamare dei veri porcili! S'io dovessi vivere in queste regioni preferirei di bruciarmi la testa, perché ti 
assicuro che nelle Province meridionali si darebbe lavoro a metà della popolazione facendo spazzare quelle che chiamano strade, prima che questi paesi giungano allo stato di civiltà di cui abbisognano anni e anni. Non strade, non alberghi, non ospedali nulla insomma di quanto si vede oggi nella parte meno avanzata d'Europa - poveri paesi! Quale Governo Dio ha permesso s'avessero! Manca loro il senso del gusto e dell'onesto, bugiardi e timidi come fanciulli! Eppure vi sono dei milionari in ogni villaggio, eppure si vedono campagne vaste ma l'uomo s'è fatto bruto - per inimicizie terribili - e in questo paese i nemici o gli avversari si uccidono [...] Questo è insomma un paese che bisognerebbe distruggere o almeno spopolare e mandarli in Africa a farsi civili! (Petraccone 2000:87, emphasis added) ${ }^{8}$

Bixio here is just expanding what we might call an 'African simile', by repeating what in 1860 the historian and politician Luigi Carlo Farini (Prime Minister for a short time in 1863) wrote to Cavour: "Ma, amico mio, che paesi son mai questi, il Molise e la Terra di Lavoro! Che barbarie! Altro che Italia! Questa è Affrica: i beduini a riscontro di questi cafoni, sono fior di virtù civile" (Mieli 2002).

Two views of the southern question are at work: on one hand, Bixio's idea of the South as just a backward land, which has not yet reached the level of civilization of advanced Europe; on the other hand, Don Fabrizio's image of the South as a millenary colony, ceaselessly occupied and 'civilised' by outsiders; hence what he calls the southern historical piega. There is nothing essentialist in the latter; a lot in the former, more so when he maintains that the southerners lack a sense of beauty and honesty, that they are liars and shy like infants. While orientalist Bixio

There is a tragic side to Bixio's views, the episode of the Bronte. See the movie Bronte: un massacro che i libri di storia non hanno mai raccontato, by Florestano Vancini. 
opposes 'modernity' to 'backwardness', "Gramscian" Don Fabrizio opposes 'hegemony' to 'subalternity'.

Given this political-cultural perspective, how could the 'medieval' South not become a colony to be exploited by northern middle-classes? How could this unification not bring about disastrous consequences in the South? Southern regions, until then 'sheltered' on one side by the 'salty water' of the Mediterranean and on the other by the 'holy water' of the Papal States ${ }^{9}$, clashed with the northern regions during the forced unification process. Eminent figures, conservative and liberal alike, emphasised the flaws of such a process. Already in 1861 Pasquale Villari, in his Lettere meridionali, denounced the inability of the northern bourgeoisie to govern the new state, becoming for the South nothing other than an oppressive and colonising force. Even the conservative Sidney Sonnino declared a decade later that for the southerners Italy meant only repression, high taxes and arrogant officials. Therefore, no sooner had the unification process been finalised, than the questione meridionale was born. Gramsci, however, was perhaps the first one to give a detailed analysis of that process, describing it as follows:

L'accentramento bestiale ne confuse i bisogni e le necessità, e l'effetto fu l'emigrazione di ogni denaro liquido dal Mezzogiorno nel Settentrione per trovare maggiori e più immediati utili nell'industria, e l'emigrazione degli uomini all'estero per trovare quel lavoro che veniva a mancare nel proprio paese. (Gramsci 2005:64)

In another passage from his Prison's Notebooks he goes even deeper:

9 The Roman Church for fear of an emerging national power, and the consequent loss of its Patrimonium Petri, interposed between the two Italies for centuries, favouring a constant political patchwork. 
La "miseria" del Mezzogiorno era "inspiegabile" storicamente per le masse popolari del Nord; esse non capivano che l'unità non era avvenuta su una base di uguaglianza, ma come egemonia del Nord sul Mezzogiorno nel rapporto territoriale di città-campagna, cioè che il Nord concretamente era una "piovra" che si arricchiva alle spese del Sud e che il suo incremento economico-industriale era in rapporto diretto con l'impoverimento dell'economia e dell'agricoltura meridionale. Il popolano dell'Alta Italia pensava invece che se il mezzogiorno non progrediva dopo essere stato liberato dalle pastoie che allo sviluppo moderno opponeva il regime borbonico, ciò significava che le cause della miseria non erano esterne, da ricercarsi nelle condizioni economico-politiche obiettive, ma interne, innate nella popolazione meridionale, tanto più che era radicata la persuasione della grande ricchezza naturale del terreno: non rimaneva che una spiegazione, l'incapacità organica degli uomini, la loro barbarie, la loro inferiorità biologica. (Gramsci 1975:2021-22)

From this passage it is clear that the backwardness or the miseria of the South was due to more than one factor: northern middle-class exploitation through legislative financial measures ${ }^{10}$; southern agrarian middle-class

10 Thus wrote Gramsci in 1916: "Il protezionismo industriale rialzava il costo della vita al contadino calabrese, senza che il protezionismo agrario, inutile per lui che produceva, e non sempre neppure, solo quel poco che era necessario al suo consumo, riuscisse a ristabilire l'equilibrio. La politica estera degli ultimi trent'anni rese quasi sterili i benefici effetti dell'emigrazione. Le guerre eritree, quella di Libia, fecero emettere dei prestiti interni che assorbirono i risparmi degli emigrati. Si parla spesso di mancanza di iniziativa nei meridionali. È un'accusa ingiusta. Il fatto è che il capitale va a trovare sempre le forme piú sicure e piú redditizie di impiego, e che il governo ha con troppa insistenza offerto quella dei buoni quinquennali” (Gramsci, 2005:64-65). 
oppression of southern peasants, who went on living under its yoke also after the unification; foreign political and economic conditioning ${ }^{11}$. It was the interaction of all these historical factors that led to the emergence of the Southern Question, factors which added to more ancient ones (i.e., the South as a millenary colony) that Tomasi di Lampedusa in his novel exposed as causes leading to the southern piega. And yet still today, this piega is considered less a historical effect than an biological state, the "question", less a consequence of the subaltern condition than a negligent delay on the path towards modernity.

In the last decade, the so-called pensiero meridiano has tried to see this piega in an alternative way. It has tried to judge it from inside, to look at it not with the usual northern modernist gaze, from which any pensiero meridionalista had suffered thus far, but with a meridian gaze. The sociologist Franco Cassano, who launched the idea of a pensiero meridiano, argues:

Se si vuole ricominciare a pensare il sud sono necessarie alcune operazioni preliminari. In primo luogo occorre smettere di vedere le sue patologie solo come la conseguenza di un difetto di modernità $[\ldots]$ non pensare il sud alla luce della modernità ma al contrario pensare la modernità alla luce del sud. Pensare il sud vuol dire allora che il sud è il soggetto del pensiero: esso non deve essere studiato,

11 The British Royal Navy, for instance, was a stable presence in the Mediterranean Sea during the $18^{\text {th }}$ and $19^{\text {th }}$ centuries: "Nella seconda metà del secolo [ $18^{\text {th }}$ century], l'egemonia del commercio inglese nel Mediterraneo, rinforzata dalla presenza regolare della Marina Reale, presidiava il disfacimento organico del rapporto complementare fra il Nord Italia commerciale e industriale e il Sud agricolo" (Chambers, 2007:119). The British Prime Minister W. Gladstone coined the famous description of the Bourbon government as "the negation of God erected into a system of Government" (cit. in Schneider 1998:5). But his liberal denunciation was not disinterested and impartial as it might appear since he saw in the Italian unification an anti-papist political process, which could favour British affairs in the Mediterranean. Small wonder then if Cavour is said to have confessed that he was more familiar with British history than with Sicily's. 
analizzato e giudicato da un pensiero esterno, ma deve riacquistare la forza per pensarsi da sè, per riconquistare con decisione la propria autonomia. (Cassano 2005:5)

In other words, the South is to be thought of and envisaged, by itself, because "pensiero meridiano vuol dire fondamentalmente questo: restituire al sud l'antica dignità di soggetto del pensiero, interrompendo una lunga sequenza in cui esso è stato pensato da altri”" (Cassano 2005:5). The South is not an incomplete North. The first step of this process then is to bring to an end the sense of inferiority, the anxiety of belated progress. The ideology of modernism is not the only possible ideological model at hand.

This approach is similar to the one fostered by Joseph Ki-Zerbo in the case of African history and culture, of which we spoke earlier. The parallelism between Cassano's and Ki-Zerbo's views can be a starting point to establish connections between the Italian South and the Global South. This hypothesis will be discussed in the last section.

\section{The Italian South and the Global South}

We have already seen some northern perspectives on the South given by a number of followers of "the whole army of peregrine martyrs" of the Grand Tour, to speak mockingly in the wake of Lawrence Sterne (1984:52). To them, Italy was the European artistic and natural orchard, and the South an exotic primitive Eden. Since 1800, from their modern industrialised homo fictus' viewpoint, with its firm belief in progress, the northern Mediterranean coast appeared to be somewhat similar to their superseded pre-industrial past and a sort of untouched world: the motionless homo naturalis' civilisation. Hence, their romantic escape from the rigours of their natural, economic and cultural climate towards 
the southern dolce far niente ('sweet idleness'), in search of ancient ruins. We have also seen that often this pleasant scenario of backwardness was replaced by the more racist views of certain outstanding champions of Italian unification.

This distinction was not only made by foreigners. Giacomo Leopardi, who in his Zibaldone (1821) juxtaposed antiquity and south on one hand and modernity and North on the other, registers the direction history has taken: "la civiltà progredisce da gran tempo (sin da' tempi indiani) dal sud al nord, lasciando via via i paesi del sud. Le capitali del mondo antico furono Babilonia, Menfi, Atene, Roma; del moderno, Parigi, Londra, Pietroburgo!" (Leopardi 1921:743). According to him, the direction of progress has always been South-North, particularly since the beginning of modernity. If this is true, the fact that global and Italian migration is moving mainly from South to North should not be much of a surprise. People moved from the South (of Italy) towards North America, first, and Northern Europe and Italy afterwards. But what about present global migration? Is the direction still the same? The picture now is more complex. Geographically, the directions are more than one, depending on which part of the planet you come from: for instance, English speaking Sub-Saharan migration is mainly towards the South, i.e., towards South Africa; not to speak of the migration towards Australia. But the South/North concept is not only geographical but also socio-economical, and in this respect we cannot deny that the direction is South-North (that is to say from subaltern to hegemonic countries). And yet, as far as the Mediterranean area is concerned, something has changed: not the migration direction but the barycentre of the movement. The Italian South is no longer (or, maybe more accurately, not only) a land of emigrants but also a land of immigrants. With the last big epochal European invasion (this time non-colonising), the Mezzogiorno was no longer the last Thule 
of Europe, but the contact-zone, the cross-zone, of global migration. In short, it has become a 'centre' in the new post-cold war world.

There has been something similar to what Gnisci calls "il rovescio del gioco" (Gnisci 2003): there are still journeys from south to north, but what has been turned upside down is the perception of noialtri southerners - for some, the South has become North. So the questions are: what happened then to the land of dolce far niente, to the primitive or ancient Eden, so many times crossed and depicted by northern travellers? How do these new pilgrims perceive us?

Let us listen to Tahar Ben Jelloun for one moment:

Coloro che non hanno altra ricchezza che la loro differenza etnica e culturale sono votati all'umiliazione e da ogni forma di razzismo. Danno anche fastidio. La loro presenza è di troppo. Il viaggio, per loro, non sarà mai di villeggiatura [...] L'immigrato è un'aberrazione dei tempi moderni. È un errore della nostra epoca. Una sbavatura della storia. (Ben Jelloun 1990:VIII)

It happens, then, that these travellers are not Grand Tour martyrs, but downright martyrs, or "damnées de la terre": those wretches whom we meet at every corner and crossroads in our Western towns, selling their meagre goods. Occidentalism has taught the wretched of the earth that the dreamed North-West is the land of freedom and wealth: "Nei caffè, la sera, si parlava della Francia e dell'Italia. Qualcuno era già partito e, si diceva, aveva fatto fortuna [...] Si pensava che il lavoro ci fosse dappertutto, le donne ci stavano e gli uomini erano tutti froci". The speaker is a young Tunisian man who leaves his own town as a tourist and finds himself in Sicily as a clandestino (Fortunato \& Methnani 
2006:12) $)^{12}$. In Rome he tried to be a tourist: "Potrei andare a visitare la Cappella Sistina e i musei Vaticani [...] Poi come tutti gli altri immigrati della capitale, me ne vado a zonzo nei pressi della stazione Termini" (Fortunato \& Methnani 2006:52). In Naples, apart from the warm solidarity of a Calabrese emigrant family, he has many squalid experiences, and after so much useless and depressing wandering about in search of a job, his journey towards the North or towards the South of the North, turns out to be a journey through his personal inner South: "Ho vomitato a lungo, con sollievo. Mi pareva di liberarmi di un'infinità di cibo cattivo e di cattivi pensieri. Alla fine, con lucidità, ho pensato che risalire l'Italia corrispondeva, nella mia personale geografia, a una discesa nel Sud di me stesso" (Fortunato \& Methnani 2006:42). His journey towards the North, because of his clandestine condition, instead of an emancipation journey, becomes an experience of decay and consequently a symbolic passage through the bodily and morally southern parts of himself: it is a descent into hell. The tourists' romantic Eden has turned into the migrants' Hell, full not only of ruins but of industrial and human waste: another "rovescio del gioco"13. This is the consequence perhaps to which Chambers refers when he writes:

12 It may be interesting here to note that in the Fifties, in Naples and other southern areas, a foreign homosexual could have sexual intercourse with young people for just one dollar. The "southern border", then, has presently just moved further south.

13 Augé claims that modernity has no time to produce ruins. Apparently, it has produced a lot of debris, though. If the direction of "human" waste is south-north, the direction of industrial waste is north-south. Roberto Saviano in his bestseller reports: "La parte più consistente dei traffici di rifiuti tossici ha un vettore unico: nord-sud. Dalla fine degli anni '90 diciottomila tonnellate di rifiuti tossici partiti da Brescia sono stati smaltiti tra Napoli e Caserta e un milione di tonnellate, in quattro anni, sono tutte finite a Santa Maria Capua Vetere [...] Le campagne del napoletano e del casertano sono mappe della mondezza, cartine di tornasole della produzione industriale italiana" (Saviano 2006:312-13). 
Quando il Terzo Mondo è non più tenuto a distanza laggiù, ma comincia ad apparire qui, quando l'incontro tra culture, storie, religioni e lingue diverse non si verifica più lungo il perimetro, nelle "zone di contatto", ma emerge al centro della nostra vita quotidiana, nelle città e nelle culture del cosiddetto mondo avanzato o Primo Mondo, forse allora possiamo cominciare a parlare di un'interruzione significativa nel senso precedente delle nostre vite, culture, lingue e prospettive future. (Chambers 2003:10)

The arrival of immigrants from the Global South turns upside down the appeasing romantic landscape built by the northern gaze. Moreover, on one hand, their lives 'interrupt' those of southerners whose self image is still emotionally involved with 'their' migrant Southerness; on the other hand, new migrants hold up a disquieting mirror for those southerners who tend to remove the memory of their past as emigrants. It is an estranging process that compels us to re-shape the perception of ourselves as southerners. Another new Italian-speaking migrant writer, Tahar Lamri, tell us that "lo straniero conosce 'in vita' l'esperienza della morte. Si muore a degli affetti, dei paesaggi, dei pensieri, per rinascere ad altri affetti, altri paesaggi e altri pensieri" (Lamri 2006:41-42). If so, then, the southern native dies with him as soon as his common sense is interrupted by the outsider's presence, but he can be born again endowed with a new sense of self. It is as if the conquest of the 'new' can be achieved through the re-appropriation of the 'past'. We are not expected to look to the past with nostalgia for 'the good old things', or to feed the essentialist idea of a South made of Blood, Land and Tradition, which is the exact reversal of the historical image of a South peopled by "lazzaroni", as Cassano convincingly points out: "In quello che noi chiamiamo passato c'è molta roba da buttar via, sopraffazioni silenziose, superstizioni crudeli, interdetti ingiustificati, ma c'è anche dell'altro, ci sono suggerimenti preziosi, 
qualcosa che può tornare utile per il futuro" (Cassano 2007:102). If we do not adopt this 'ecologic' attitude towards our past, or towards what we consider belonging to an outdated world, our present loses something crucial, and its neurotic, solipsistic, and almost erotic, run towards the future is unrestrained by nothing. Therefore, the migrant's outlook may be a chance for us to consider tradition in a non traditional way.

Coming back to De Martino's study, he insisted on considering 'tarantism' not as an individual illness but as a social institution, because it implied an ethos, or, in his own words, "una mediata volontà di storia, un progetto di 'vita insieme', un impegno ad uscire dall'isolamento nevrotico per partecipare ad un sistema di fedeltà culturali e ad un ordine di comunicazioni interpersonali tradizionalmente accreditato e socialmente condiviso" (De Martino 2002:178). In modern(ist) society, this kind of social bond, this collective dimension, is a rare thing, besieged as it is by radical individualism and the apology of the idea of freedom as something completely apart from the sense of responsibility towards the other. According to Spivak, there are two kinds of community: the responsibility-based ones, like Islamic society, where human individual rights are neglected, and rights-based communities, such as North/ Western ones, where, on the contrary, what is neglected is the sense of social responsibility. Therefore, the epistemological lesson to be learned by pre-modern or pre-capitalist communities, as the Bengalese scholar would have it, can be that "you have to fix the possibility of putting not just wrong over against right, with all the genealogical lines compressed within it, but also to suggest that another antonym of right is responsibility, and further, that the possibility of such responsibility is underived from rights" (Spivak 2004:534). Of course the other way around is also the case in point, as Spivak does not fail to remind us. She is not "suggesting that they [responsibility-based communities] are better, just that they are different, and this radically different pair - rights and 
responsibility - need to relate in the hobbled relationship of supplementation" (Spivak 2004:545). Would it follow, then, that the "individualist democratic" North needs to be supplemented by the "holistic responsible" South, and the archaic undeveloped South needs to be supplemented by the modern developed North? The answer might be positive, but only if we bear in mind two points. Firstly, the $20^{\text {th }}$ century historicist pair "developed/underdeveloped"14 cannot displace the $19^{\text {th }}$ century ontological pair 'superior/inferior'. Secondly, following Pasolini's denunciation during the most fast-developing Italian period, (economic) development is not automatically (social) progress.

Il "progresso" è [...] una nozione ideale (sociale e politica): là dove lo "sviluppo" è un fatto pragmatico ed economico. Ora è questa dissociazione che richiede una "sincronia" tra "sviluppo" e "progresso", visto che non è concepibile (a quanto pare) un vero progresso se non si creano le premesse economiche necessarie ad attuarlo. [...Non si può] confondere mai, neanche per un solo istante, l'idea di "progresso" con la realtà di questo "sviluppo". (Pasolini 1999:456)

The separation is the separation inborn within North/West consumer society, which mistakes development for progress. A dissociation that can be synchronised through what Cassano calls "misura", which is not, "un'intesa minima far le culture [...] un semplice giro turistico nella cultura dell'altro, ma un prenderla sul serio, un provare ad imparare qualcosa da essa" (Cassano \& Zolo 2007:79). And what can the global North learn from the global South? Maybe this: development and rights

14 It was the American President Harry Truman who first implied this opposition in his inauguration speech (1949), by declaring that large areas of the world were "underdeveloped". These large areas were of course what we now call the Global South. 
can be turned into progress only if peoples all over the planet can responsibly share its benefits.

This is probably what Gnisci means when he invites the Europeans to 'decolonise their minds': "La 'civiltà europea' [... ] è pronta ora, in queste condizioni conosciute e riconosciute, a decolonizzarsi dalla sua malattia imperiale, dall'eurocentrismo rimasto come residuo 'nobiliare' della funesta volontà di potenza" (Gnisci 2007:120). This is how we can now interpret De Martino's idea according to which the land of remorse is not only that remote Mediterranean region called Apulia but the whole planet, whose evil past-spider comes back to bite and re-bite its inhabitants. In the late Fifties he already had a planetary vision of questions. Global immigration, a sort of spontaneous people's bio-politics, can be interpreted as the return of the repressed colonised-colonising past, which haunts the colonised as well as the colonisers. The latter will try in vain to stop the spider from re-biting. The colonisers' remorse will not go away, unless they accept the idea that something wrong happened in their past and that the remedy for those wrongs is a curing social dance, in which everybody can take part with their own different rhythm. The Italian Mezzogiorno, presently once more invaded, as it happened so many times in its long history, is not only part of the West. It is one of the regions that form that 'pluriverse' called Mediterranean (the forgotten cradle of Europe), whose main quality has historically been hybridity. Even the most apparent typical Mediterranean feature (such as diet, flora, music, etc.) is the result of an ancient crossbreeding: its oranges have been imported from the Far East, its chilli peppers from the New World, even the melancholic tonality of the Italian voice owes so much to Arab music.

Following on from Fanon's prayer, let us ask a final question: can this be the costly experience the Italian South has to offer the Global North (of which it is part), while being invaded by the Global South?

(Università di Bari) 


\section{Bibliography}

Auden, W.H.

Bodini, V.

Bodini, V.

Bodini, V.

Calvino, I.

Calvino, I.

Campanella, T.

Cassano, F. \& Zolo, D. (eds)

Cassano F.

Cecere, A. (ed)

Chambers, I.

Chambers, I.
1970 Introduction. In: Goethe, J.W., Italian Journey [1786-1788]. Harmonsworth: Penguin.

1979 La Puglia contro Pietro Micca. L'Albero, 61-62:130-134.

1997 Tutte le poesie. Nardò: Besa.

2007 Squinzano, vino a Milano. Nardò: Besa (orig. 1950).

1967 Galleria, n. 3-6, A. Marcovecchio (ed.).

1995 Cibernetica e fantasmi. In: Calvino, I., Una pietra sopra, Discorsi di letteratura e società. Milano: Mondadori (orig. 1980).

1995 La città del sole. Roma: Newton \& Compton (orig. 1602).

2007 L'alternativa mediterranea. Milano: Feltrinelli.

2005 Il pensiero meridiano. Bari: Laterza (orig.1996).

1993 Viaggiatori inglesi in Puglia dell'Ottocento. Fasano: Schena.

2003 Paesaggi migratori. Roma: Meltemi.

2007 Le molte voci del Mediterraneo. Milano: Raffaello Cortina. 
De Martino, E.

De Martino, E.

de Staël, M.

Evelyn, J.

Fortunato, M. \&

Methnani, S.

Gissing, G.

Gladstone, W. E.

Gnisci, A.

Gnisci, A.

Gramsci, A.

Gramsci, A.

Ben Jelloun, T.

Lamri, T.
2002 La terra del rimorso. Milano: Net (orig. 1961).

2007 Sud e magia. Milano: Feltrinelli (orig. 1959).

1998 Corinne ou l'Italie. Oxford: Oxford University Press (orig. 1807).

1955 The Diary of John Evelyn. Oxford: E.S. de Beer (orig. 1818).

2006 Immigrato. Milano: Bompiani (orig. 1990).

1996 By the Ionian Sea, Notes of a Ramble in Southern Italy. Evanston: Marlboro Press (orig. 1900).

1851 Two Letters to the Earl of Aberdeen, on the State Prosecutions of the Neapolitan Government. London: Murray.

2003 Creolizzare l'Europa. Letteratura e migrazione. Roma: Meltemi.

2007 Decolonizzare l'Italia. Roma: Bulzoni.

1975 Quaderni dal carcere. Torino: Einaudi.

2005 La questione meridionale. Roma: Editori Riuniti.

1990 Le pareti della solitudine. Torino, Einaudi.

2006 I sessanta nomi dell'amore. Sant'Arcangelo di Romagna: Fara Editore. 
Leopardi, G.

Levi, C.

Mernissi, F.

Mieli, P.

Mozzillo, A.

Pasolini, P.P.

Petraccone, C.

Saviano, R.

Schneider, J. (ed)

Spivak, G. Chakravorty
1921 Zibaldone di pensieri. Firenze: Le Monnier (orig. 1820).

1990 Cristo si è fermato a Eboli. Torino: Einaudi (orig. 1945).

2001 Scheherazade goes West. Different cultures, different harems. New York: Washington Square Press.

2002 Il pregiudizio negativo nei confronti del Meridione. Corriere della Sera, February 1st.: 41 (online: http://archiviostorico. corriere.it/2002/febbraio/01/pregiudizio negativo_nei_confronti_cel_co_0_ 0202011324.shtml).

1982 Viaggiatori stranieri nel Sud. Milano: Edizioni di Comunità.

1999 Sviluppo e progresso. In: Pasolini, Pier Paolo, Tutte le opere. Milano: Mondadori.

2000 Le due civiltà. Settentrionali e meridionali nella storia d'Italia dal 1860 al 1914. Bari: Laterza.

2006 Gomorra. Milano: Mondadori.

1998 Italy's "Southern Question”: Orientalism in one country. Oxford-New York: Berg.

2004 Righting Wrongs. South Atlantic Quarterly, 103: 2/3, Spring/Summer:523-581. 
Sterne, L.

Tomasi di Lampedusa, G.

Walpole, $\mathrm{H}$.

1984 A Sentimental Journey and other writings. Oxford: Oxford University Press.

002 Il Gattopardo. Roma: Mediasat (orig. 1958).

003 The Castle of Otranto. Toronto: Broad View Press (orig. 1764). 